\title{
A Glimpse into the Antithetical Poetic World of Vihang A. Naik
}

\author{
Goutam Karmakar ${ }^{1}$ \\ ${ }^{1}$ Department of Humanities and Social Sciences, NIT Durgapur, West Bengal, India \\ Correspondence: Goutam Karmakar, Department of English, Bhagilata High School, Raiganj, West Bengal, \\ India. E-mail:goutamkrmkr@gmail.com
}

Received: February 13, 2016

Accepted: February 19, 2016

Online Published: February 29, 2016

doi:10.20849/ajsss.v1i1.22

URL: http://dx.doi.org/10.20849/ajsss.v1i1.22

\begin{abstract}
Antithesis and rapidity mark the pattern inVihangA.Naik's poems with a complete correctness that deserves an amount of considerable appreciation. He had used imagery in a vivid and descriptive language to add an inner depth to his work. As a result, it appealed to the human senses deepening the reader's understanding of the work. He makes use of particular words that creates an emotional intensity in the reader's mind. Antithesis is a contrast or opposition either rhetorical or philosophical and this term was cultivated especially by Pope and other eighteenth century poets. In philosophy, an antithesis is a second argument or principle brought forward which sharply contrasts ideas that are juxtaposed in a balanced or parallel phrase structure. It is a literary device to put two contrasting ideas together and this emphasizes the difference between the two ideas and adds an interest to writing. His poetic world consists of antithetical statements that have been part of our everyday speech and are profoundly employed in the arguments and discussions in his poems. He had employed it in not only sentences but also in modern society and events. This paper mainly deals on the fact upon how he had used it extensively by equally showing the good and the bad facets of city life. He occupies a distinctive position as a poet and his poems involve contemplation or absorption into spirituality in respect to modern life, much beyond the earthly vision or the worldly understanding. He reflects upon the mind that has been lost in thematerialistic pursuit of the world. His simple theme of city life is expressed with stark sincerity and his influence upon the reader is immense and builds up an emotion that compass his poetic style by introducing a new range of experiences in city life.
\end{abstract}

Keywords: antithesis, society, life, pollution, globalization, nature

\section{Introduction}

Before going to the discussion let's discuss the term 'Antithesis'. It denotes nothing but the mere and strong contrast and opposite forces between the clauses and phrases and the contrast is presented in such a structural way that enables the reader to give a definite look at it. It is a figure of speech and is amply used to give vividness to an ordinary speech and it also presents the speech in such a way that make a difference from the speeches used in ordinary everyday speech. The poet had contrasted ideas bringing together by expressing the theme in a more clear way. He examines the pros and cons of the realities of modern city life bringing forth the judgment on this particular matter by discussing it in his poem. He had employed it to create figurative language that adorns and fixes adding imagery to his poems. The main modern city life style patterns have been discussed by him in his poem 'City times':

"There

The road unwinds,

Where

You'll pick up

The race

And melt away

In the noises

Of a city 


\section{Whose streets}

Lead you nowhere" (City times and other poems, p. 14)

Post-modernist poetry reflects a variety of themes. Since this age is filled by politics, social, cultural and economic problems, therefore modern poetry deals with the current issues of social life in modern times. This form of poetry represents the world of life standing face to face with several questions of existence. VihangA.Naik's poems are a distinguished piece of post-modernist literature. His poetry reflects Freudian internal conflict, a problem that must be solved implying a new era of post-modernism. His poems have proved to be great poetical achievements. His poems are filled with striking imagery, symbolism and structural economy with a vivid prediction of life. His poems consist of technical innovations with a common purpose and philosophy to give an intellectual standing. Born in the year 1969 at Surat in Gujrat, he has given the world of poetry lovers four collection namely 'Poetry Manifesto: New and selected poems' (2010), 'Making a poem' (2004), 'City times and other poems' (1993). His Gujarati collection of poems entitled 'Jeevangeet' was published in 2001. Materialism exists in physical matter, negates thought, feeling, human will and faith and it promotes the idolatry of possessions that is believed to fill all human need and characterization of quality life. There is a lack of empathy and engagement with others and this materialism is what the poet suggests that is both socially destructive and a process of self-destruction. It smashes the happiness and peace of mind of those who succumb to it associating with anxiety, depression and broken relationships. The dreadful mistake of man is that they are allowing themselves to believe having more stuff enhancing well-being but this worldly ambition, material assumptions, perpetual growth, are a formula for man's unhappiness. He makes a difference about the transcendent existence and random existence. The random existence is explained by showing the modern life of a person's city life whereas, the transcendental existence is what the poet is mainly concerned about as he explains in his poem 'Self-Portrait':

"I wake up to see my self

Discovered beyond thought" (Poetry Manifesto, p. 97)

The important feature in his poem is the sociological ideal which is strongly propagated simultaneously showing the positive and negative facets of the society. His poetry is social and realistic and he is found to have taken an immense interest in the modern society making an analytical, sincere, critical and satirical survey of the modern age and society in his works. His poems remain rich in intellectual gifts that become a storehouse of social sketches, personal views, critical invectives, intellectual pursuits and moral ideals. He is both realistic, idealistic and prescribing certain principles for the elevation of love above all earthly fears and threats of modern love. "The poet is well versed in linguistic deviations chiefly of graph logical deviation. He discards the rules of graphology and punctuation chiefly to heighten the effect. Sometimes, he writes the word in small letters in order to euphemistically ridicule or elevate the importance while at the other time, he capitalizes the words to lambast or mirror the over heightened effect of the same word"(Singh, Shaleen Kumar. Poetry Manifesto, by Vihang Naik, 2011).Extravagances in images, intricate and far-fetched analogies, extreme fancifulness and emotional exuberance are highly bounded and they are found strongly manifested in his poems. His artistic excellence lies in the range of thoughts and conceptions and his poems had an effect on the existing literary pattern along with the strong inclination to correctness with a distinct mark of clearness, plainness and directness. According to him, technology have put man on the highest branch and the misuse of all of these have created a diverge in the society. In society the modern people cannot imagine their lives without the use of technology and this have been helping people to live more luxuriously. This advancement of technology is depicted in his poem 'New Websight':

"Your vision

Makes an inductive

Leap

The fear grips

An e-age as the century

Turns" (Poetry Manifesto, p. 11)

But with more luxuries come the negative effects on people and society as a whole. The poet provides the antithetic view of both advantages and disadvantages of modern city life allowing the readers to make a contrast of the paradoxical situations existing in the society. Without doubt, modern life has been changed considerably. City streets clogged with automatic traffic clearly reflects the modern city life: 


\section{"A river turns}

Into a gutter. There is humming

Of vehicles. The city mumbles

\section{U grapple for meaning}

In the traffic of noises" (Poetry Manifesto, p. 14)

Nowadays people command more plentiful supply of good. The progresses of modern life have many drawbacks and in his view, it is true that today modern man in society moves more swiftly through the world. But in doing so, he often loses track of roots and traditions that give substance and meaning to life, leading to a superficiality of thought. Modern life has given man the gift of leisure of a longer life but in return life has become more restless, busy and uncomfortable. People living the society finds the appetite for material things increased but never satisfied with it. The poet throws light upon the other aspect of modern life. Modern life style pattern has its negative effects as people physically, psychologically and socially become adjusted to the use of high technology. However, no one can ignore the usefulness of modernization on city life as it makes life easier. He exclaims that depression or disillusionment primarily stem from modern living and social isolation. It damages a person's life mentally and socially and will deprive the individual from normal life. Even modern city life affects the social relationships strongly as people hardly have time to reach others in their fast, busy life leading to social isolation. This as a result, comes out by getting deprived from social gatherings and love relationships. This reduces an individual's productivity and development of the communities in the society. The poet makes a sharp contrast upon the positive and negative sides of city life. The poet had a frustrated acceptance of modern life as colorless and joyless. The social trend expands and there is a considerable increase in the magnitude of the perspective of life. The artistic consciousness to fascinate a reader takes birth in his poetry. He draws the multiple aspects of human personality revealing the themes of direct experiences and the problems of human life and human nature with varying attitudes to modern life. He had presented an unvarnished picture of life, laying special emphasis or forces that are the result of frustration to modern life springing from human passions upon the working of society. He is mainly objective in his attitude towards modern city life and he had exploited certain incidents of his life in his poems. He states that a city enjoys a position of pride for its rich amenities which are necessary for the modern way of life and city life has its own glamour which attracts people from underdeveloped areas because of its comforts and its cultural, economic and commercial facilities. The poet talks about the metaled roads in the city in his poem 'The Banyan City':

"The old banyan

Is no more. You can no longer click

That tree at the crossroad" (Poetry Manifesto, p. 14)

One can come to the conclusion that because of the pressure of urban population, cities are now extremely congested. City life is now spoiled by the various pollutions and there has been multiplicity of motorized vehicles in city roads causing a lot of traffic problems. He reflects upon the situation of the historic transformation on a global scale that consists of village culture being rapidly replaced by urban culture. Migration from the countryside to city areas is merely a new phenomenon. Therefore he states that urban life ensure the fact that inevitably life becomes more and more rapid in the city and people just walk hurriedly without even giving some notice to the vital things in life that are family and nature as in his poem 'City times and other poems' he states :

"You

Become a touch,

Letters of words;

A perfumed card

In

A changed city" (Poetry Manifesto, p. 87)

He holds that city life is very appealing but its developing rates are harmful for man's survival in future. One can notice that the lifestyle varies between a city life and a village life and this variation of differencein the lifestyles have been aptly drawn by the poet. New ventures, opportunities and experiments happen in cities but the lifestyle is not as advanced like city life, the culture and attitude of people in village life are more warm and welcoming. 
The question of city life comes with more polluted air, polluted river water, busy and materialistic life as depicted in his book 'City Times and other poems':

"An inspired child

Sketches of nuclear war

The world shivers

A polluted planet

The ganga screams for help" (City times and other poems, p. 71)

Naik is a poet per excellence in creating and mixing emotions such as feelings, thoughts, disgust. Pity, sorrow, joy, pain, pleasure, victory, defeat, depression, frustration, enthusiasm and many more and his poetic corpus shows these opposite aspects in a very beautiful way. Each moment on journey of life are presented with an opportunity to react differently. He talks about the problems of materialistic craze for possession in this modern life, the problem of love and the human predicament, the futility and meaninglessness and loneliness of the human lives. These harrowing experiences of humanity are objectively put into words in his poetry. They present a criticism of material values and there is a note of frustration raised with the obsession with material values of life portraying realistically the sordidness of life. His poetry focused the attention on the presentation of a man's life from infancy to old age. He speaks about his varied experiences of life and love. His appreciation of art and literature equipped his mind and prepared him for selecting poetry as a form of art. He somehow confirms with the view of Wordsworth in terms of imagination which gives a solid foundation to his poetry. Not only that, he also tries to give a pen-picture of the world through his poetry. Readers may also find similarity between Naik and Tennyson in terms of thought expression and ornateness. Poems from this volume show his potentiality to create phrases and images. An intense love for natural beauty, a profound sympathy for man, a keen interest with golden past, an emotional subjectivity are the featured and perceived parts in his works. The spirit is struck in the liberation of creative inspiration and emotion in art and letters as in his poem 'Making a Poem' he states:

"How about making a poem within

A poem? You smell the ocean and

The sand

A life within a poem" (Poetry Manifesto, p. 61)

In the period of globalization, materialism comes to be an important fact. He feels saddened and disheartened to see the sad plight of the contemporary times gripped with the notion and objectivity of physical pleasure depicting the realistic picture of ecological awareness. The hectic lifestyles of the people have turned from bad to worse and people are futile in different to the glorious past of the city where they are presently living in. There is a lack of ecological consciousness in his poem. The poet tries to find out something that is of a meaningful purpose of human existence.Deterioration and loss of physical beauty of trees and the nature makes the poet sad as he notices the weird development of the city in the guise of highway and stone sculpture where there is no actual presentation of the natural heritage. The last poem 'city times' shows the poet's innocence that he had passed and reflects on how he has been shaped and changed to maturity. The city with its complexities is used to reflect on the disillusioned life. This sense of uselessness of life is further reflected in his poem that is common call to the people to let the light remove the pervading darkness from the world. "Life is a hollow word for him and he finds it equal to an absurd play. Same feelings are expressed in The Final Act. Striking imagery, captivating metaphors and subtle use of other figures of speech add a fresh glory and grace to his poems. The first half of the book is devoted to concepts such as versification, poetic language, and tradition, the second half is organized along genre lines and examines, nature poetry, sociological experience" (Dixit, Dr. Kalyani. "Colossal Range Of Experiences And Philosophical Vision Of Vihang A. Naik In Poetry Manifesto: New And Selected Poems, Research Scholar 1.4, 2013: 1-4). Each poem is well perceived and filled with imagery of hope and sadness, sensitive thoughts or the innocence of childhood, his discoveries of youth and the disillusionment with manhood. A sense of exile and self-alienation is prevalent in his poems through the hectic routine of city life. Each mood of life is brought and examined though the poet's illuminating experience of city life. The emotional intensity can be found with an insight into the realities of modern life.His poetry represents a decentered concept of the universe where individual works are not isolated creations in the fabric of literary creation. His adoption of style combines or pastes together multiple elements that show his advancement of poetry in a unique way. His poetry embraces the notion that literature is a created work of art and is a strong example in contemporary literature. His poetry throws the reader into the world of various interrelated aspects . 
He portrays pictures and images in a subtle precise, sharpen and realistic way. So his poetry bear the marks of imagination and realism. He expresses an individual's emotions of being utterly lonely in this city life.

\section{Conclusion}

According to the poet's view, city living in the $21^{\text {st }}$ century is stressful and offers no advantages. His observation and understanding is based on man in society. Hence it is reflective and philosophic by studying man in the perspective of his place in the society and nature. His work remains an example of the most conscious and accomplished art with an impulsive and humanitarian touch. This is supplemented by the fondness with an exclusive characterization that includes love for humanity, interest in nature and imaginative propensity. Clear description and profound reflections constitute much of his poetry and his base of the poems lies absolutely on the beauty as well as the diversity of the nature. His poetic world mentions about a feeling of disappointment in human life arising from the realization about something that is possibly accompanied by an urban angst. The poet's voice is exceptional that one cannot avoid or overlook. He feels ruined by the unhappiness of the city life and he had been feeling the good and bad sides of it in an antithetic way. A close look to his City times poems show the bare image of the city life and here he presents every phrases, words and images in a clear precise way with a lot of examination, scrutiny and sculptures of abstract life. The way of changing lifestyle and its effect on quality of life of the individual and community is constantly fluctuating as expressed through his suitable poems. His intuitive and antithetical lines instill among the readers a state of numbness and anxiety taking a forward step into the inward journey of a man and explaining how the outward life has captured people. The false appearance and the deceptions have become the major weapon of modern man. The poet takes his readers on a voyage of discovery against the backdrop of a city scape with an unnerving ability to see inside the hearts and minds of his readers with an undisputed talent for translating complex emotions with astonishing simplicity. His poetic life evokes an inner solitude of our individual selves with the poetic expressions alluding to the spiritual and metaphysical contents of life reaching the higher territories of sharp intellectualism in life.

\section{References}

Kalyani, D. (2013). Colossal Range Of Experiences and Philosophical Vision of Vihang A. Naik In Poetry Manifesto (New And Selected Poems). Research Scholar, 1(4), 1-4.

Karmakar, G. (2015). Vision Of Life And Poetic Creation: A Study of Vihang A. Naik's Poems. The International Journal of Social Sciences and Humanities Invention, 3(2), 1836-1840. Retrieved from http://valleyinternational.net/thijsshi/v3-i2/2\%20theijsshi.pdf

Naik, V. A. (1993). City times and other poems. Kolkata: Writer's workshop.

Naik, V. A. (2004). Making A Poem. New Delhi: Allied Publishers.

Naik, V. A. (2010). Poetry Manifesto (New and Selected Poems). New Delhi: Indialog Publications Pvt. Ltd.

\section{Copyrights}

Copyright for this article is retained by the author(s), with first publication rights granted to the journal.

This is an open-access article distributed under the terms and conditions of the Creative Commons Attribution license (http://creativecommons.org/licenses/by/3.0/). 